\title{
Motives and Effectiveness of Forex Interventions: Evidence from Peru
}


Motives and Effectiveness of Forex Interventions: Evidence from Peru

Melesse Tashu 


\title{
IMF Working Paper
}

Western Hemisphere Department

\section{Motives and Effectiveness of Forex Interventions: Evidence from \\ Peru Prepared by Melesse Tashu*}

Authorized for distribution by Alejandro Santos

December 2014

\section{This Working Paper should not be reported as representing the views of the IMF. The views expressed in this Working Paper are those of the author(s) and do not necessarily represent those of the IMF or IMF policy. Working Papers describe research in progress by the author(s) and are published to elicit comments and to further debate.}

\begin{abstract}
This paper assesses empirically the motives and effectiveness of forex interventions in Peru. While the central bank of Peru states that its forex interventions aim only at containing excessive exchange rate volatility, the results of this paper show that, in practice, the interventions seem to have aimed at "leaning against the wind" as well. The results also show that forex sales, but not forex purchases, react to volatility, indicating asymmetry in the central bank's reactions to episodes of appreciation and depreciation pressures. Similarly, the paper documents evidence of asymmetry in the effectiveness of forex interventions.
\end{abstract}

JEL Classification Numbers: E5, E6, F3, G1

Keywords: Capital flows, FX intervention, FX purchase, FX sale, FX volatility

Author's E-Mail Address:MTashu@imf.org

\footnotetext{
- The author is grateful to Alejandro Santos, Adrián Armas, Paul Castillo, Marco Ortiz, Fernando Perez Forero, Evan Tanner, Svetlana Vtyurina, and participants in the presentations at the IMF's WHD seminar series and at the BCRP for their valuable comments and feedbacks.
} 


\section{Contents}

I. Introduction $\quad \underline{3}$

II. Capital Flows and FX Interventions $\quad \underline{4}$

III. Methodology $\quad \underline{8}$

A. Literature Review $\quad \underline{8}$

B. Method of the Study $\quad \underline{9}$

IV. Data and Estimation Results $\quad \underline{14}$

A. Data Sources $\quad \underline{14}$

B. Descriptive Analysis $\quad \underline{14}$

C. Estimation results $\quad \underline{17}$

V. Concluding Remarks $\quad \underline{21}$

Annex I. Single Equation Regression of the Central Bank's Reaction Function $\underline{22}$

Annex II. The Exchange Rate Target Estimated By Six Months Moving Average

Exchange Rate $\quad \underline{23}$

Annex III. The Exchange Rate Target Estimated By One Year Average Rolling HP Filtered Exchange Rate

Annex IV. Tolerable Range Defined As 1-Year Historical Average Exchange Rate \pm 1.5 Times Standard Deviation

References 


\section{INTRODUCTION}

Capital flows to Peru have grown significantly in recent years, reflecting both push (easy money in advanced economies) and pull (strong fundamentals of the Peruvian economy) factors. While a large share of these flows is foreign direct investment (FDI), the growing size and volatility of portfolio and short-term flows is a source of concern as these often lead to the buildup of risks and vulnerabilities in the financial system.

While utilizing prudential measures to contain the buildup of financial and macroeconomic risks, on a daily basis, the Central Reserve Bank of Peru (BCRP) relies on Forex (FX) intervention to safeguard the FX market against the pressures from large and volatile capital flows. In 2013 alone, the BCRP intervened with FX purchases of US\$5.2 billion through April and with FX sales of a similar amount between July and December in the spot market, reflecting the volatility of capital flows. The BCRP intervenes with a stated objective of containing volatility in the FX market. The pattern of its intervention, however, suggests that 'leaning against the wind' could also be another objective of the intervention.

This paper aims to assess empirically the motives and effectiveness of FX interventions in Peru. The effectiveness is assessed not only against officially stated objectives but also against other motives empirically "revealed" by the data. In this regard, the paper estimates a reaction function of the BCRP to identify the "revealed" motives of the BCRP's interventions and to address the simultaneity problem between FX interventions and exchange rates. In doing so, the paper also tests if there is asymmetry in the BCRP's responses to appreciation and depreciation pressures and if there is asymmetry in the effectiveness of interventions between FX purchases and FX sales.

The paper employs an innovative empirical approach to address the potential simultaneity problem between FX intervention and exchange rate movements. In particular, the paper devices instrumental variables based on information on the specific timing of FX interventions by the BCRP and intra-daily exchange rate data. Although BCRP's FX intervention is not pre-announced, intervention decisions are made every day by a committee that meets between 11:30AM and 1:00PM. Hence, the paper uses exchange rate movements before 11:30AM to estimate the BCRP's reaction function and uses the predicted values of the likelihoods of FX interventions from the estimated reaction function as instruments for FX intervention in the exchange rate equations. The dependent variables of the exchange rate equations in the second stage regression are changes in the level and volatility of the exchange rate between the PM and AM trading sessions.

The remainder of this paper is structured as follows. Following this introduction, Section II highlights capital flows and FX interventions in Peru, followed by a discussion of methodological issues in Section III. Section IV presents data and estimation results, and Section V concludes the study. 


\section{CAPITAl Flows AND FX Interventions}

Peru has received large amounts of capital inflows in recent years. Net capital flows amounted to about 8 percent of GDP a year, on average, during 2010-13, well above the regional average ${ }^{1}$ (about 5 percent of GDP) and the average of the last decade for Peru (about 6 percent of GDP). Gross inflows amounted to about 91/2 percent of GDP a year during 2010-13 (Figure 1). This surge in capital flows reflects both push factors (easy money and low interest rates in advanced economies) and pull factors (strong domestic fundamentals). In advanced economies, interest rates hit bottom and monetary aggregates hiked significantly following the recent global financial crisis, pushing a glut of financial flows to emerging economies ${ }^{2}$. Meanwhile, Peru has become an increasingly attractive destination for capital flows with a record of high economic growth (about $6 \frac{1}{2}$ percent a year during the last decade), strong terms of trade (TOT), and sound monetary and fiscal policies.

Although a large share of the capital flows to Peru has been FDI, the volatility and growing pace of portfolio and short-term flows have raised concerns. Despite the authorities' efforts to encourage capital outflows to ease appreciation pressures (including by increasing the limits on external investment by pension fund managers), net portfolio inflows continued to increase as Peruvian firms' demand for external financing increased to take advantage of the low global interest rates. External bond issuance by Peruvian firms doubled to US $\$ 61 / 2$ billion (3.2 percent of GDP) in 2013, from US\$3 billion (1 1/2 percent of GDP) in 2012.

Empirical evidence shows that surges in capital inflows are associated with excessive expansion of credits, asset price bubbles, real exchange rate appreciations, and current account deteriorations, which are likely to lead ultimately to financial and economic crisis (Reinhart and Reinhart, 2008; Cardarelli et al, 2010; Furceri et al 2012). While avoiding capital control measures, the Peruvian authorities implemented preventive measures, including accumulating international reserves, strengthening macro-prudential policies, and encouraging capital outflows to avoid the buildup of vulnerabilities associated with capital flows. Consequently, early signs of overheating (with credit growth of over 20 percent and significant appreciation of stock and housing prices in 2011) moderated towards the end of 2012 despite the continuation of capital inflows.

\footnotetext{
${ }^{1}$ The average net capital flows to Brazil, Chile, Colombia, Mexico, and Uruguay.

${ }^{2}$ Tapering of U.S. Federal Reserve's purchase of securities starting in the second half of 2013 has already slowed the pace of capital flows to emerging market economies, including Peru.
} 


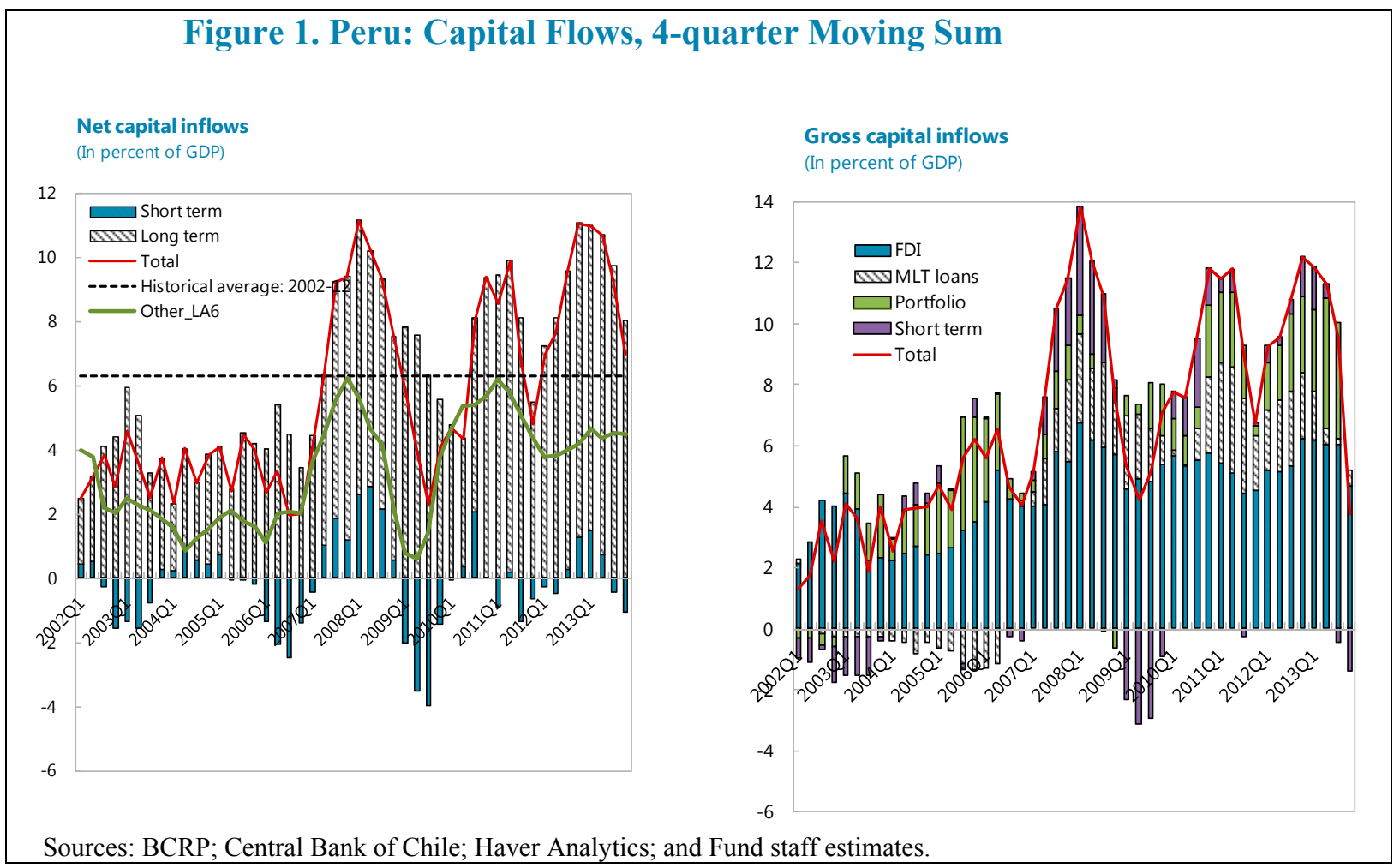

On a daily basis, however, the authorities use FX intervention to safeguard the FX market and the financial system from the impact of high and volatile capital flows. Peru's FX market is an interbank market based primarily on spot transactions. The derivatives market is not well-developed and is limited to very small forwards and options transactions. Trading in the spot market is also thin. Consequently, modest changes in capital flows can generate volatilities in the FX market (Figure 2), with potential impacts on balance sheets and the buildup of vulnerabilities in the financial system due to relatively high financial dollarization. ${ }^{3}$ As a result, the BCRP tries to reduce exchange rate volatility by intervening in the FX market.

Interventions are conducted mainly in the spot market and occasionally through making swaps and sales of dollar-indexed securities (equivalent to selling FX forward) (Rossini et al 2011 and 2013). By and large, FX interventions by the BCRP are not pre-announced. ${ }^{4} \mathrm{FX}$

\footnotetext{
${ }^{3}$ Despite significant progress in reducing financial dollarization over the last decade, credit and deposit dollarization remain high at around 40 percent.

${ }^{4}$ The exception is between September 2012 and April 2013, when BCRP purchased FX almost on a daily basis after announcing in August 2012 that it will purchase more stable amounts of FX even during days of depreciating pressures, while keeping the amounts of intervention unannounced. The decision was taken due to concerns of predictable appreciating pressure on the nuevo sole and the strategy sought to generate higher exchange rate volatility. (BCRP, 2012; Rossini et al, 2013)
} 
interventions during the recent episodes of capital inflows have led to reserve accumulation. Net international reserves (NIR) stood at about US $\$ 65.7$ billion (about 32 $\frac{1}{2}$ percent of GDP) as of end-2013. These interventions were mostly sterilized through issuance of BCRP securities, Treasury deposits and reserve requirements. BCRP securities denominated in local currency are sold to financial institutions and have a return of about 4 percent (and a 4 percent fee is charged on transfers of the securities to non-financial entities to ensure that they do not attract further capital inflows from non-residents). The BCRP has also sold FX during times of depreciation pressures such as following the Lehman crisis, the euro zone crisis, and recently following the United States Federal Reserve Board's announcement of unconventional monetary policy tapering. FX sales are also mostly sterilized (local currency liquidity injected) mainly through swaps and repos.

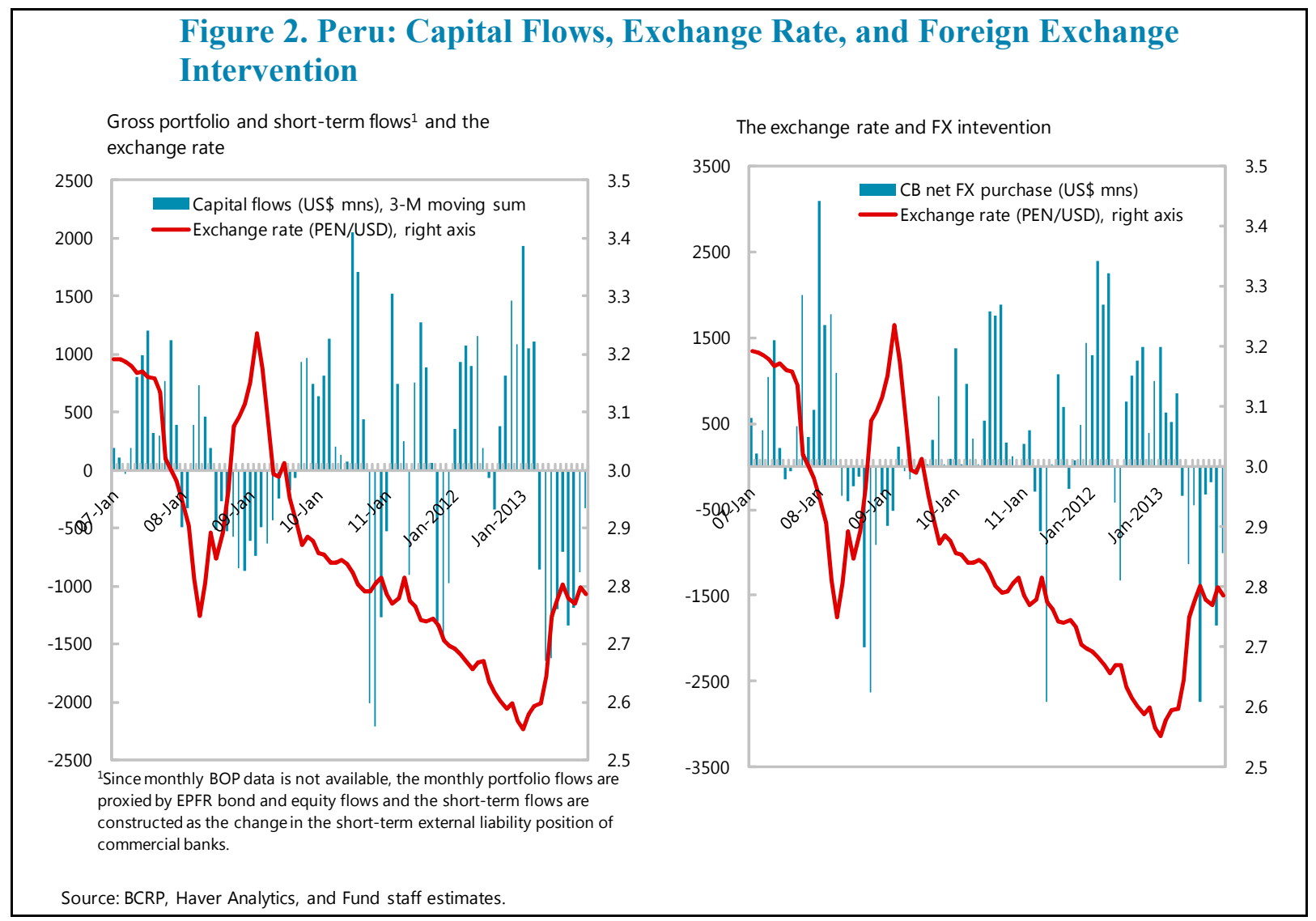


FX interventions absorb a significant amount of FX pressures. A foreign exchange market pressure (EMP) index ${ }^{5}$ is estimated and then broken down by the pressures on the exchange rate and that on the NIR. The EMPI index shows that FX interventions absorb a significant share of the pressures from capital flows although the authorities continue to allow increasing exchange rate flexibility. While the increases in FX reserves during periods of high capital inflows can in principle be the result of a reserve buildup motive, recent FX interventions in Peru seem to have been motivated mainly to ease the pressure on the exchange rate. For instance, the NIR was already high at end-2011, and the FX interventions since then could have most likely been conducted to ease FX pressures.

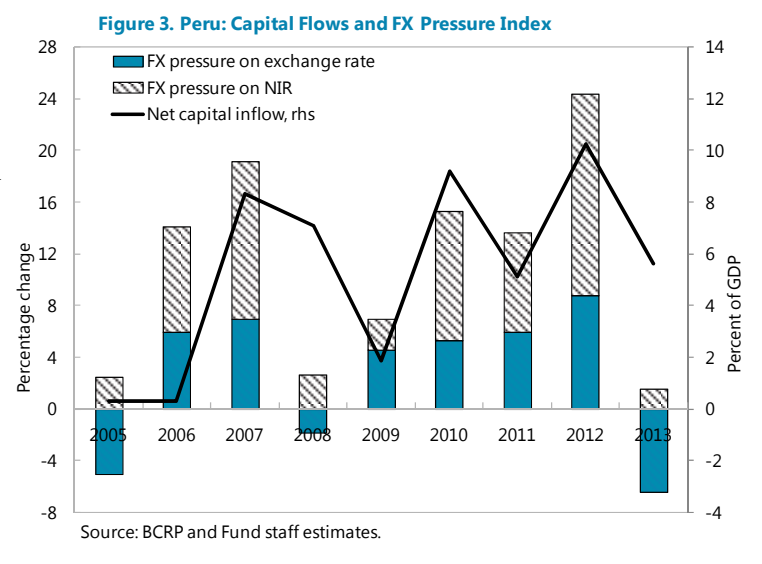

Statistical evidence suggests that containing volatility may not be the only objective of FX intervention in Peru. The BCRP's FX intervention before May 2013 was concentrated on FX purchases and in the second half of 2013 on FX sales, indicating that FX interventions might be aimed at more than just containing volatility. In other words, the pattern of the BCRP's intervention may indicate attempts to lean against the wind or to limit the rate of appreciations/depreciations. Empirical studies have also found evidence that the deviation of the exchange rate from its trend induces FX intervention in Peru (see Gonzalez, 2009; Humala and Rodriguez, 2009). Furthermore, contrary to the stated objective, the BCRP's intervention during September 2012-April 2013 appears to have increased volatility.

The purpose of this paper is to empirically investigate the motives and effectiveness of FX interventions in Peru. To achieve these goals, the paper proceeds in two steps. First, the BCRP's reaction functions are estimated separately for FX purchases and sales to shed light on the motives of interventions, which may vary between episodes of appreciations and episodes of depreciations. Second, the likelihoods of interventions, predicted from the first stage regressions, are used as instrumental variables for FX interventions (to overcome potential simultaneity biases) in the exchange rate equations. The next section discusses details of methodological issues.

\footnotetext{
${ }^{5}$ The index tries to measure exchange rate and reserve accumulation pressures. It is calculated as the sum of the percentage change in the exchange rate and the percentage change in reserves, following the empirical literature (Aizenman and Hutchison, 2012; Cardarelli et al, 2010). The exchange rate is defined, for this purpose, in terms of U.S. dollars per nuevos soles so that the pressure on the exchange rate has the same sign as the pressure on FX reserves.
} 


\section{Methodology}

\section{A. Literature Review}

The literature identifies two channels through which a sterilized intervention can affect the level of the exchange rate: the portfolio balance and signaling effects. ${ }^{6}$ According to the portfolio balance approach, sterilized intervention alters the composition of agents' portfolio as central banks buy/sell domestic assets in their sterilization effort, and thereby the relative prices of domestic and foreign currency denominated assets, assuming that these assets are imperfect substitutes in investors' portfolios (Dominguez and Frankel, 1993; Sarno and Taylor, 2001). Alternatively, foreign exchange intervention could work through the signaling channel if central bank interventions are perceived by private agents as a signal for future policy stance or as a means of disseminating information about exchange rate fundamentals, assuming the central bank has superior information (Dominguez and Frankel, 1993; Sarno and Taylor, 2001; Kearns and Rigobon, 2005).

Efforts to empirically test the impact of foreign exchange interventions on the exchange rate are often hampered by potential simultaneity biases. While intervention could affect the exchange rate, the decision to intervene is not independent of movements in the exchange rate (Dominguez and Frankel, 1993; Galati et al, 2005; Kearns and Rigobon, 2005; Disyatat and Galati, 2007). Even after the central bank has decided to intervene, the timing and amount of the intervention depends on the reaction of the exchange rate to the initial intervention (Kearns and Rigobon, 2005; Disyatat and Galati, 2007).

A common solution to the simultaneity problem is the use of lagged intervention variable (see, for instance, Dominguez and Frankel, 1993; Baillie and Osterberg, 1997; Guimaraes and Karacadag, 2004; Broto, 2012). But this method may underestimate the true impact of interventions, as part of the impact may be reflected through lagged values of the dependent variables, which are often included among the explanatory variables (Galati et al, 2005). Furthermore, central banks often intervene with the aim of influencing not only future movements but also contemporaneous movements of the exchange rate.

Another approach employed in recent empirical studies is event study style regressions. This method attempts to address the simultaneity problem by precisely identifying the time of intervention and relating it to the exchange rate returns using a very high frequency intra-daily data (see, for instance, Dominguez, 2003 and 2006). ${ }^{7}$ However, this method may

\footnotetext{
${ }^{6}$ Dominguez (2003 and 2006) also shows how intervention can affect the intra-daily exchange rate returns through a third channel, the microstructure channel. This approach shows how heterogeneity among traders, based on their differences in understanding and interpreting information revealed through central bank information, can affect the short-run value and volatility of the exchange rate.

${ }^{7}$ Dominguez (2003 and 2006) runs regressions of 5-minute exchange rate returns (mean and volatility) on (time-stamped to the nearest 5-minute) signed intervention and other announcement dummy variables.
} 
not resolve the simultaneity problem if central banks base their intervention decisions on intra-daily exchange rate movements or volatility (Dominguez, 2003). That said, there is evidence that central banks are more likely to base their intervention decisions on longer-term objectives, although the size of the interventions may be determined by market reactions to the initial interventions (Neely, 2001). ${ }^{8}$ Unfortunately, this method demands very high frequency (minute-by-minute) data on exchange rates and interventions, which is not publicly available for Peru.

A third approach to addressing the simultaneity bias is using an Instrumental Variable (IV) method. The method involves estimating a central bank's reaction function and using predicted values of intervention from the estimated reaction function as an instrument for intervention in the exchange rate equation (see, for instance, Galati et al, 2005; Kearns and Rigobon, 2005; Disyata and Galati, 2007; Adler and Tovar, 2011). The common practice is to use lagged values of the exchange rate in an ordinary least squares (OLS) estimation of the central bank's reaction function. The exclusion of the contemporaneous values of the exchange rate could, however, create an omitted variable bias, although the bias could be trivial since there is no empirical evidence of persistence in exchange rate moments ${ }^{9}$ (Galati et al, 2005).

\section{B. Method of the Study}

This paper employs an IV estimation method to assess the effectiveness of FX intervention in Peru. However, unlike the common practice of using lagged exchange rates in the reaction functions, the paper uses the same-day exchange rates, taking advantage of intra-daily exchange rate data availability and the approximate timing of FX interventions. The FX market in Peru operates between 9:00AM and 1:30PM local time and decisions on FX interventions are made every day by a committee that meets between 11:30AM and 1:00PM (Lahura and Vega, 2013), indicating that interventions are conducted after 11:30AM ${ }^{10}$. On the other hand, intra-daily exchange rate data is publicly available for 3 specific points in time: market opening (around 9:00AM), 11:00AM, and market closing (1:30PM). The paper uses exchange rate movements during the AM session to estimate the BCRP's reaction function. Predicted values of the likelihoods of FX interventions from the BCRP's reaction

\footnotetext{
${ }^{8}$ Two-thirds of 22 central banks surveyed by Neely (2001) indicate that they intervene in the FX market to align the exchange rate to "fundamental values," and about 90 percent of them indicate that the purpose of their intervention is to resist short-run trends. But 95 percent of the respondents report that market reactions to their initial intervention sometimes or always affects the size of the intervention.

${ }^{9}$ Consequently the correlation between the included lagged moments and the omitted contemporaneous moments is likely to be negligible.

${ }^{10}$ The decision to intervene in the afternoon may also be motivated by the fact that most FX dealers aim to close their positions by the end of the trading day, leading to increased flow of transactions on the closing hours. Thanks to Marco Ortiz and Fernando Perez Forero of the BCRP for pointing out this comment.
} 
function are then used as instruments for FX interventions in the regressions for changes in the exchange rate (both the level and volatility) between the PM and AM sessions.

The assumption is that the BCRP makes intervention decisions after observing the behavior of the exchange rate during the morning trading session. This method minimizes the possibility of omitted variable bias in the second stage of the regressions. Furthermore, interventions are used in the form of dummy variables since the daily dollar amounts of interventions may depend on market reactions to the initial interventions and hence may create a simultaneity bias. The model also assumes that intervention decisions by the central bank are completely unanticipated by the market, otherwise expectations for intervention could affect the behavior of the exchange in the morning trading session and create simultaneity bias. This assumption is consistent with the BCRP's discretionary intervention strategy except during September 2012-April 2013.

In particular, the BCRP is assumed to intervene in the FX market when the level and volatility of the exchange rate deviate from implicit target ranges following the standard literature (for example, Sarno and Taylor, 2001; Galati et al, 2005; and Disyatat and Galati, 2007) ${ }^{11}$. The likelihood of the central bank's intervention depends on the extent of the deviations. This can be represented by the following equation:

$$
I N T_{t}=\alpha_{0}+\alpha_{1}\left(s_{t}-s_{t}^{*}\right)+\alpha_{2}\left(\sigma_{S_{t}}-\sigma_{S_{t}}^{*}\right)+\varepsilon_{t}
$$

where INT is the dummy for intervention ( 1 when the BCRP intervenes, 0 otherwise), $\mathrm{s}_{\mathrm{t}}$ and $s_{t}^{*}$ are logs of the actual and target levels of the PEN/USD exchange rate, $\sigma_{S}$ and $\sigma_{S}^{*}$ are the actual and target volatility of the exchange rate, $\varepsilon$ is the random error term, and $t$ is the time index.

Each period, the BCRP is assumed to set its target ranges for the level and volatility of the exchange rate based on historical averages. The main results of the paper are obtained based on exchange rate level and volatility targets estimated by one-year simple moving average, but the exercise is replicated with 6-months simple moving average and one-year rolling Hodrick-Prescott filtered average targets (for the level of exchange rate only) to test if the results are robust to changes in the time length and method of averaging.

Equation (1) is estimated using a probit model for FX purchases and FX sales separately to capture the potential asymmetry in the BCRP's reactions to episodes of appreciations and

\footnotetext{
${ }^{11}$ International reserve accumulation could be another potential motive for FX purchases, but this is not included in our model since the central bank is less likely to have a daily target for international reserves. Furthermore, since international reserves were already high in Peru, it is less likely to be a principal motive for FX intervention during the sample period of this study, in particular in 2012 and 2013.
} 
depreciations. ${ }^{12}$ For FX sales, INT is a dummy variable with 1 on days of FX sales and 0 otherwise. Similarly, for the equation for FX purchases, INT equals 1 on days when there were FX purchases and 0 otherwise. There is empirical evidence on asymmetry of central bank intervention in the FX market (Ramachandran and Srinivasan, 2007; Pontines and Raja, 2011; Lahura and Vegas, 2013). For instance, volatility is likely to be a main concern and a reason for intervention during episodes of depreciations than episodes of appreciations, as the former are often associated with anxiety and stresses in the financial market. On the other hand, motives for intervention during episodes of appreciation are likely to be reserve accumulation and leaning against the wind to prevent real exchange rate appreciations and current account deficit deteriorations. The fact that central banks of developing countries have a limit on FX sales, due to the zero lower bound on FX reserves, but can purchase FX without limit, at least in principle, can be another source of asymmetric central bank intervention ${ }^{13}$.

The intervention rules are defined as follows:

- The BCRP intervenes to prevent excessive appreciations and depreciations. The BCRP's tolerable range is assumed to be the target exchange rate, estimated by historical average, plus or minus one standard deviation. The BCRP intervenes to prevent excessive appreciations if the exchange rate during the morning (AM) trading session ${ }^{14}$ falls below the lower bound of its tolerable range (defined here as the historical average minus one standard deviation) and intervenes to avoid excessive depreciations if the exchange rate during the morning trading session exceeds the upper bound of its tolerable range (defined here as the historical average plus one standard deviation). ${ }^{15}$

Consequently, the exchange rate gap (deviation) is derived as follows:

$$
\left(s_{t}-s_{t}^{*}\right)=\left\{\begin{array}{l}
\left(s_{t}-s_{t}^{* u}\right) \text { if the exchange rate rises above the upper bound } \\
\left(s_{t}^{* l}-s_{t}\right) \text { if the exchange rate falls below the lower bound }
\end{array}\right.
$$

\footnotetext{
${ }^{12}$ A single equation for intervention, defined as a multinomial dummy of ' 1 ' for FX purchases, ' 0 ' for no-intervention and ' -1 ' for FX sales, is also estimated using a multinomial logistic regression as a robustness exercise for the test of asymmetry in the central bank's reaction to episodes of appreciation and depreciation (results are discussed in Section IV).

${ }^{13}$ Thanks to Marco Ortiz and Fernando Perez Forero of the BCRP for pointing out this comment.

${ }^{14}$ Due to lack of higher frequency data, the morning (AM) session exchange rate is calculated as the average of the opening (9:00AM) and the 11:00AM exchange rates.

${ }^{15}$ In a similar setup, Galati et al (2005) uses the historical average \pm 1.5 standard deviation as target bounds for the yen/dollar exchange rate. Given the low variability of the PEN/USD rate, this study tightens the target bound to \pm 1 standard deviation, although the model is re-estimated using ' $\pm 1.5 *$ standard deviation' target bound to see if the results are sensitive to the width of the target bound.
} 
$\alpha_{1}$ is expected to be positive in both cases since the likelihood of intervention increases with increasing exchange rate gap.

- The BCRP intervenes to contain excessive volatility. Intervention takes place if the volatility of the AM trading session (as measured by the square root of the squared deviation of the AM session exchange rate from the weekly average exchange rate) exceeds the historical average weekly standard deviation. A higher volatility gap is expected to increase the likelihood of intervention.

Predicted values of interventions, estimated likelihoods of intervention, from the above regressions are used as instrumental variables for FX intervention in the exchange rate equations below (2 and 3). Both estimated likelihoods of FX purchase and FX sale enter the equations for the level and volatility of the exchange rate in addition to control variables (other potential factors which could affect the daily variability of the exchange rate). The dependent variables are defined as the differences between the PM session levels ${ }^{16}$ and the corresponding AM session levels.

$$
\begin{aligned}
& \Delta e r_{-} p m_{t}=\beta_{0}+\beta_{1} I N T_{-} p u r_{t}+\beta_{2} I N T_{-} \text {sale }_{t}+\beta_{3} \text { Control }_{t}+\epsilon_{t} \\
& \Delta v o l_{\_} p m_{t}=\gamma_{0}+\gamma_{1} I N T \_p u r_{t}+\gamma_{2} I N T_{-} \text {sale }_{t}+\gamma_{3} \text { Control }_{t}+\mu_{t}
\end{aligned}
$$

Where $\Delta e r \_p m_{t}$ is the difference between the closing exchange rate and the exchange rate at 11:00AM, and $\Delta v o l_{-} p m_{t}$ is the difference between the PM session volatility ${ }^{17}$ and the AM session volatility. INT_pur $r_{t}$ is dummy for FX purchase, INT_sale $t_{t}$ is dummy for FX sale, and Control is the other control variables as defined below.

$I N T \_p u r_{t}$ and $I N T \_s a l e_{t}$ enter the regression equations separately to test for potential asymmetric responses to FX purchases and sales. Asymmetric responses may result if FX purchases and FX sales signal different information to the market (Lahura and Vega, 2013). For instance, FX purchases during episodes of appreciation may be perceived as an effort by the central bank to build international reserves. Such accumulation of international reserves may in turn attract more capital inflows, due to improved self-insurance against external shocks, and weaken the effectiveness of the FX intervention. On the other hand, FX sales by the central bank during episodes of depreciation can be effective as the intervention may be perceived by the market as a signal that the central bank is attempting to correct misalignments in the exchange rate. Empirical evidence for asymmetric effects of FX interventions has been found by Lahura and Vega (2013) for Peru and Broto (2013) for Brazil, Chile, Colombia, and Peru.

\footnotetext{
${ }^{16}$ Due to data limitations, the 1:30PM (closing) exchange rate is used as the PM session exchange rate.

${ }^{17}$ The PM session volatility is measured by the square root of the squared deviation of the PM session exchange rate from the weekly average exchange rate.
} 
In theory, control variables include the unexpected components of major economic data announcements (surprises), measured by the differences between the officially announced data and the corresponding average analyst estimates just before the announcement (see for instance Dominguez, 2003 and 2006; Galati et al, 2005; Disyatat and Galati, 2007). However, the announcements of major economic news in Peru and the U.S. (economic growth, CPI, unemployment, and the policy rate), with the exception of GDP growth in Peru, are made either early in the morning or after the FX market closes and are not expected to have differential impacts on the morning and afternoon exchange rate variability. The Peruvian authorities announce monthly economic growth data sometime around noon and, as a result, the difference between the announced GDP growth rate and the average estimates before the announcement (in absolute value terms for the volatility equation) are included to equations (2) and (3). In addition, indicators for regional and global factors are included. The change in the Chicago Board of Exchange Market Volatility Index (VIX) between the opening and closing quotes is included in the volatility regression to capture the impact of global market volatility, which is expected to be positive ${ }^{18}$. On the other hand, the daily change (between market opening and closing) in the common factor (principal component) of LA $6^{19}$ exchange rates is included in the exchange rate equation to capture the impact of regional factors, such as the impact of commodity prices, which is also expected to be positive.

\footnotetext{
${ }^{18}$ Ideally, the changes in VIX should have been between the 1:30PM and 11:00AM quotes to match the changes in the dependent variables. But minute-by-minute historical quotes are not available for the period of coverage of this study.

${ }^{19}$ Brazil, Chile, Colombia, Mexico, Peru and Uruguay.
} 


\section{DATA AND ESTimation RESUlts}

\section{A. Data Sources}

Data on daily (11:00AM and 1:30PM) exchange rates and daily FX interventions are obtained from the online statistical database of the BCRP. Data for the opening session exchange rate for Peru, exchange rates for other LA6 economies, and analysts' consensus estimates of GDP are from Bloomberg. Finally, VIX data is obtained from Chicago of Board Options Exchange (CBOE) online database. The sample covers daily data for 4 years (January 2010- December 2013), a total sample of 982 observations. ${ }^{20}$

\section{B. Descriptive Analysis}

Statistical analysis of the exchange rate and intervention data suggests that intervention decisions are prompted mainly by the deviations of the level of the exchange rate from a notional target range. In particular, FX purchases are strongly associated with the deviation of the level of the exchange rate from the lower bound of the BCRP's tolerable range. However, FX sales are conducted during episodes of exchange rate depreciations even when the level of the exchange rate falls within the target range, possibly due to volatility concerns. In general volatility is high during periods of depreciations as shown by the widening of the target range

Figure 4. Peru: Exchange rates and FX intervention

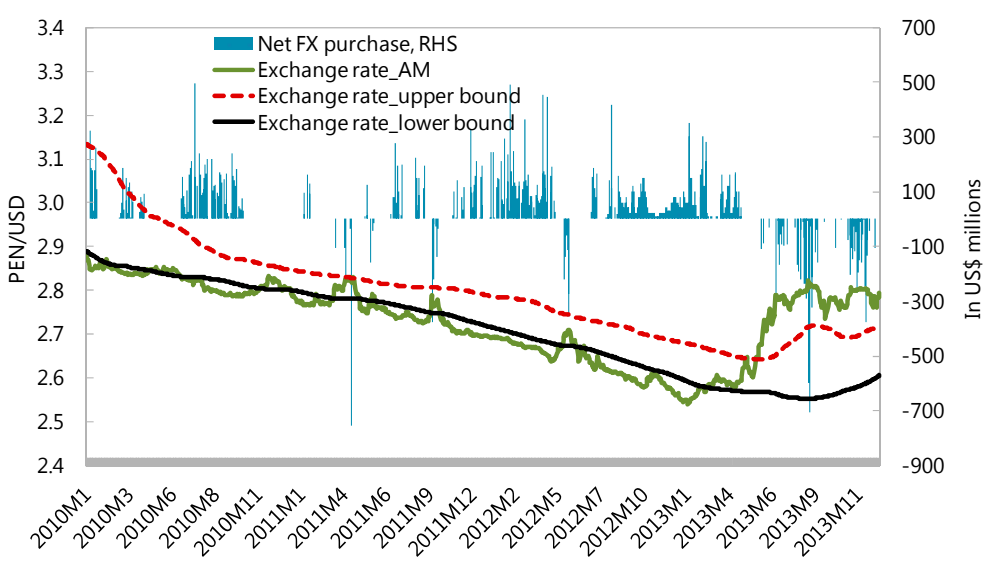

Sources: BCRP and Fund staff estimates. in the second half of 2013.

FX purchases seem to be driven primarily by the deviation of the exchange rate from the BCRP's notional tolerable range (leaning against the wind). About 91 percent of the FX purchases were conducted during days when the level of the morning session exchange rate fell below the lower bound of the notional tolerable range. ${ }^{21}$ Less than 5 percent of the FX purchases were conducted during days when only exchange rate volatility deviated from the target, while the level of the exchange rate remained within target (Figure 5).

\footnotetext{
${ }^{20}$ Of the 982 observations, BCRP purchased FX in 354 days (36 percent of total observations), sold FX in 81 days ( $81 / 4$ percent of total observations), and did not intervene in 534 days $(551 / 2$ percent of total observations).

${ }^{21}$ It refers to purchase days, not the number of purchase events. The BCRP could intervene several times during the day, but intervention data is available only on a daily basis.
} 


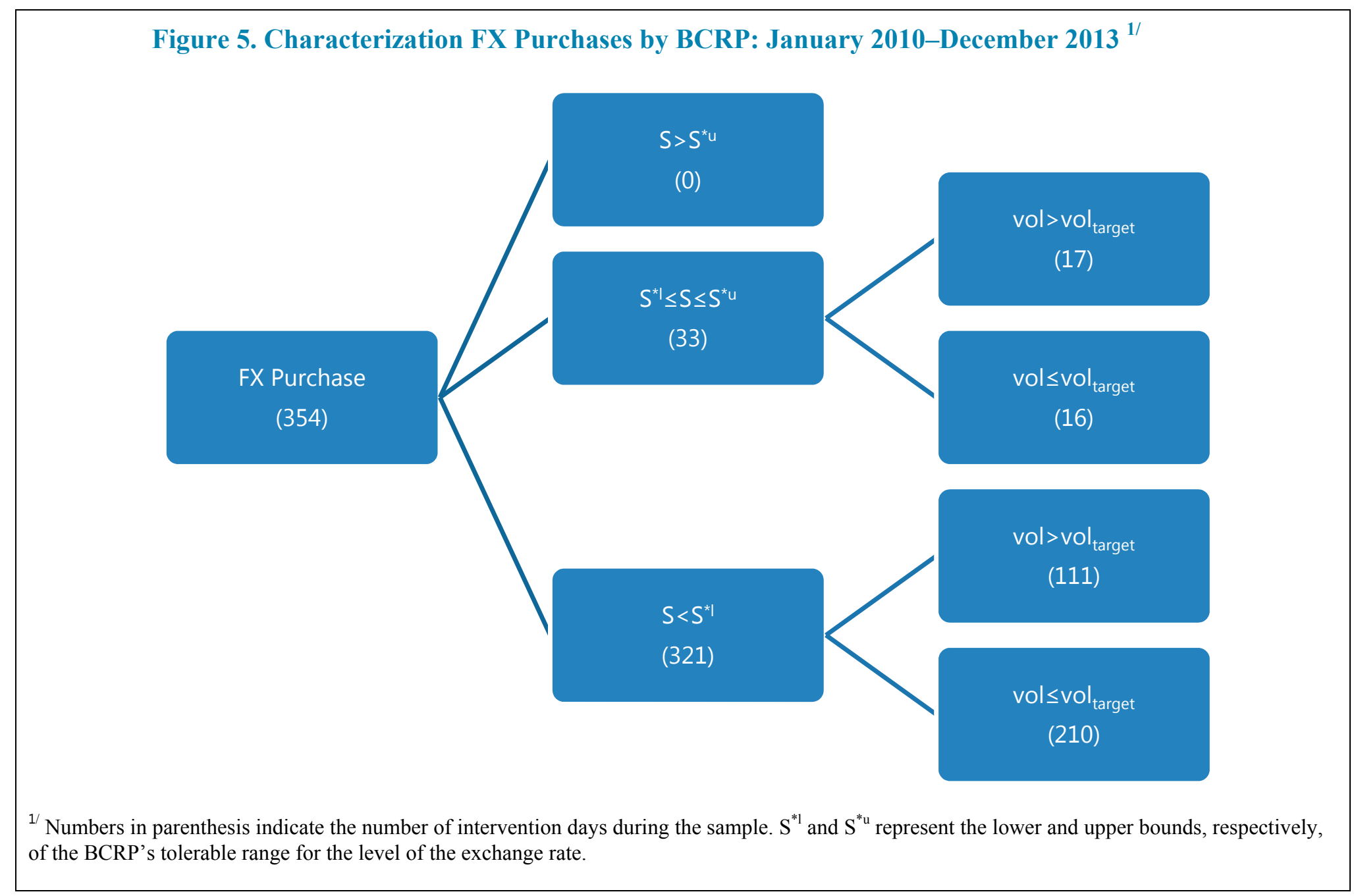




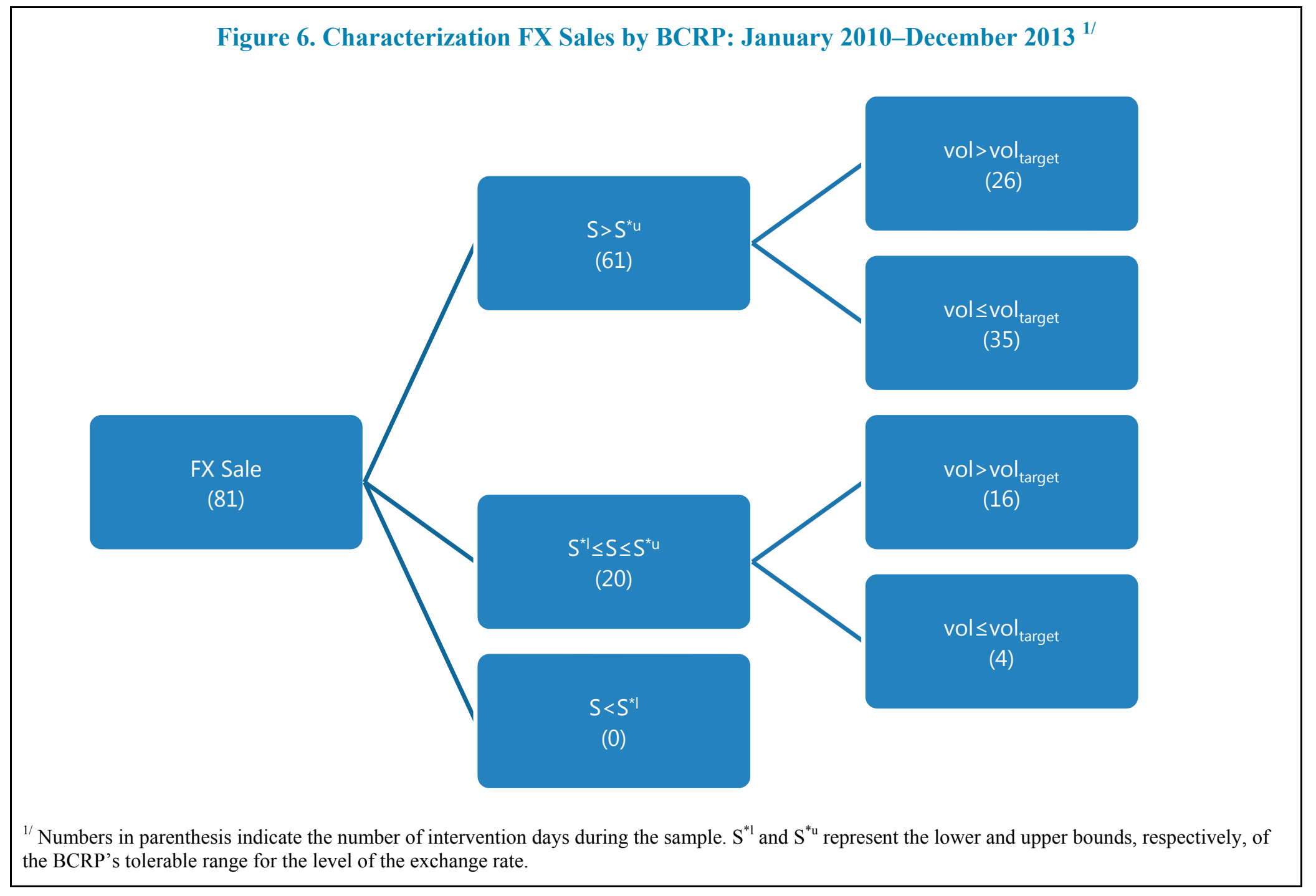


However, leaning against the wind does not seem to be the only target of FX sales. Compared to FX purchase days, a lower proportion (75 percent) of the FX sales was conducted during days when the morning session exchange rate deviated from the upper bound of the BCRP's notional tolerable range. On the other hand, relatively large share of the FX sales (about 20 percent) were conducted during days when the exchange rate volatility deviated from the target while the level remained within the BCRP's tolerable range (Figure 6).

\section{Estimation results}

\section{The BCRP's reaction functions}

The BCRP's reaction functions are estimated by probit regressions. The estimated regressions seem to explain intervention decisions very well. The likelihood ratio (LR) statistics and the Pseudo $\mathrm{R}^{2}$ values are large, indicating strong goodness of fit. Two-day lags of the dependent variables are found to be statistically significant indicating the tendency of intervention clustering (Table 1).

The results provide strong evidence that the BCRP intervenes to prevent excessive appreciations and depreciations (deviations from the notional tolerable range). Deviations of the level of exchange rate from the lower and upper bounds of the BCRP's notional tolerable range are positively and significantly associated with FX purchases and FX sales, respectively indicating that such deviations prompt FX interventions (Table 1). But the BCRP's reaction to volatility appears to be asymmetric. While the deviation of the exchange rate volatility from the BCRP's target is positively and significantly associated with FX sales, its correlation with FX purchases is negative but not statistically significant. This seems to indicate that excessive exchange rate volatility seems to be more of a concern for the BCRP during episodes of depreciations.

Regression (2) in Table 1 was estimated with the addition of dummy for intervention policy change, interacted with excessive exchange rate appreciation and exchange rate volatility, to test if the BCRP's preannouncement of interventions in August 2012 was associated with change of its reactions to exchange rate movements. ${ }^{22}$ The results do not change in a significant way. The BCRP's reaction to excessive appreciation remains statistically significant. Its reaction to excessive volatility remains negative, but becomes weakly significant, suggesting that the BCRP might have intervened out of a concern for too low volatility, which is not in line with its general stated objective.

The results of the BCRP's estimated reaction function are robust to changes in estimation methodology. For instance, the main results remain unchanged when a single equation

\footnotetext{
${ }^{22}$ The dummy takes ' 1 ' during September 2012-April 2013, the appreciation episode when the central bank's new intervention strategy was applied, and 0 otherwise.
} 
reaction function, instead of separate reaction functions for FX purchases and FX sales, is estimated using a multinomial logistic regression (Annex I). ${ }^{23}$ In particular, the odds of FX purchases are affected only by excessive appreciations, but the odds of FX sales are affected both by excessive depreciations and volatility.

Table 1. Peru: Probit regression results for the probability of FX intervention 1/

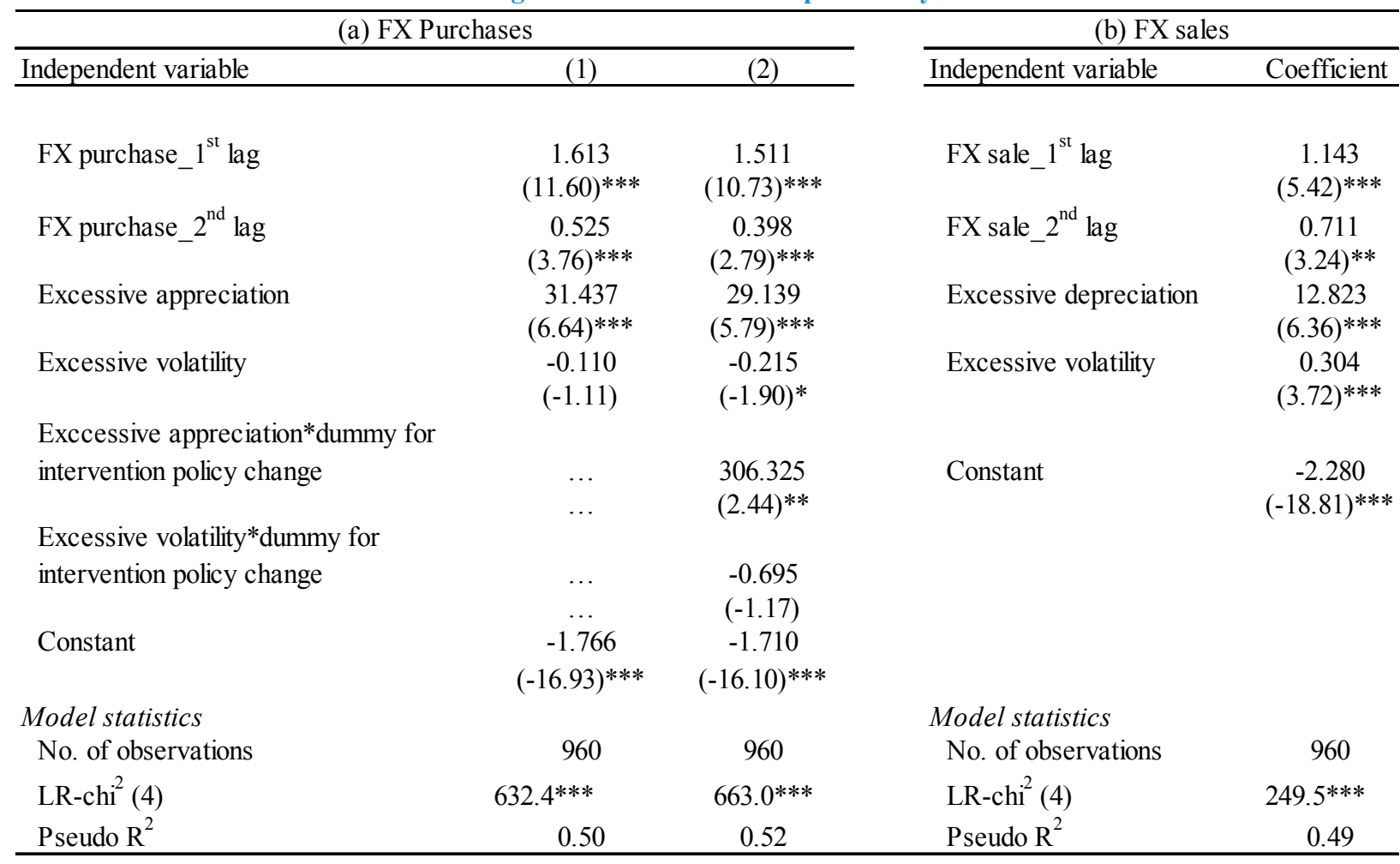

1/ Purchase and sale of FX are represented by dummy variables with values of 1 when there was purchase (sale) and 0 otherwise.

Equations (1) and (2) are without and with intervention policy change dummy interaction, respectively.

Numbers in parentheses are z-values. * significant at $10 \%$; * Significant at $5 \%$; and $* * *$ Significant at $1 \%$.

\section{Impacts of FX interventions}

Instrumental variable estimates for the level and volatility of the exchange rate provide evidence for asymmetric effects of FX interventions on exchange rate variability (Table 2). Three regressions are estimated each for the change in the level and volatility of the exchange rate (Table 2). Regression (1) includes only FX intervention variables (FX purchases and $\mathrm{FX}$ sales) ${ }^{24}$, whereas regression (2) includes other control variables.

\footnotetext{
${ }^{23}$ The dependent variable is a dummy that takes ' 1 ' for FX purchase, '-1' for FX sales, and ' 0 ' for no-intervention. Multinomial logistic regression, instead of multinomial probit, was used because no convergence was achieved using multinomial probit regression.

${ }^{24}$ Statistically significant variables in regressions (1) and (2) of Table 1 are used as instruments for likelihood of FX sales and purchases, respectively.
} 
Regression (3) includes interaction of a dummy variable for intervention policy change with FX purchase.

According to the results, there is no strong statistical evidence to suggest that FX purchase by the BCRP is successful in preventing an appreciation of the exchange rate as the likelihood of FX purchases is either statistically insignificant (regressions (1) and (2) ) or only weakly significant (regression (3)). But the likelihood of FX purchase has a statistically significant and negative impact on volatility, indicating that FX purchase by the BCRP reduces volatility. In other words, although the BCRP's objective for intervention during episodes of appreciation is to lean against the wind, it ends up reducing volatility without having a significant impact on the level of the exchange rate.

On the other hand, FX sales appear to be successful not only in reducing volatility, but also in preventing the depreciation of the exchange rate although some of the impacts appear to be reversing the following day. These results are consistent with findings of Lahura and Vega $(2013)^{25}$ that FX sales are more successful in preventing depreciation than FX purchases in preventing appreciation. With the exception of the first lag of FX sales, lags of FX intervention are not found to be statistically significant indicating that the impacts of interventions are short lived.

Unfortunately, the overall fits of the estimated models are not good, as is the case with similar empirical studies on exchange rates. The variables included in this study explain very little about the exchange rate variability. This is in part due to the fact that not all potential determinants are included due to limitations on daily data, but it also reflects the difficulty of explaining exchange rate variability. Among the control variables, only the common factor (principal component) of the exchange rates of LA6 economies became statistically significant, reflecting the importance of regional common factors such as the impact of commodity prices.

The results are robust to changes in the definition of the target and tolerable range of the exchange rate. The above regressions were re-estimated for the target exchange rate defined as a 6-month moving average and a 1-year Hodrick-Prescott (HP) rolling filtered average and for the tolerable range defined as a 1-year historical average \pm 1.5 times the standard deviation. The results both for the BCRP's reaction function and the exchange rate regressions, presented in Annexes II-IV, show that the conclusions drawn above are robust to changes in the definition of the target and tolerable range of the exchange rate. The only exception is that volatility became statistically significant in the FX purchase equation when the BCRP's tolerable range is broadened to a 1-year historical average $\pm 1.5 *$ standard deviation, in particular in the second regression. But the coefficient remains negative, still supporting the hypothesis of asymmetric BCRP reaction.

\footnotetext{
${ }^{25}$ The authors employ event study regressions and structural VARs.
} 
Table 2. Peru: Estimated impacts of FX intervention on the level and volatility of the exchange rate $1 /$

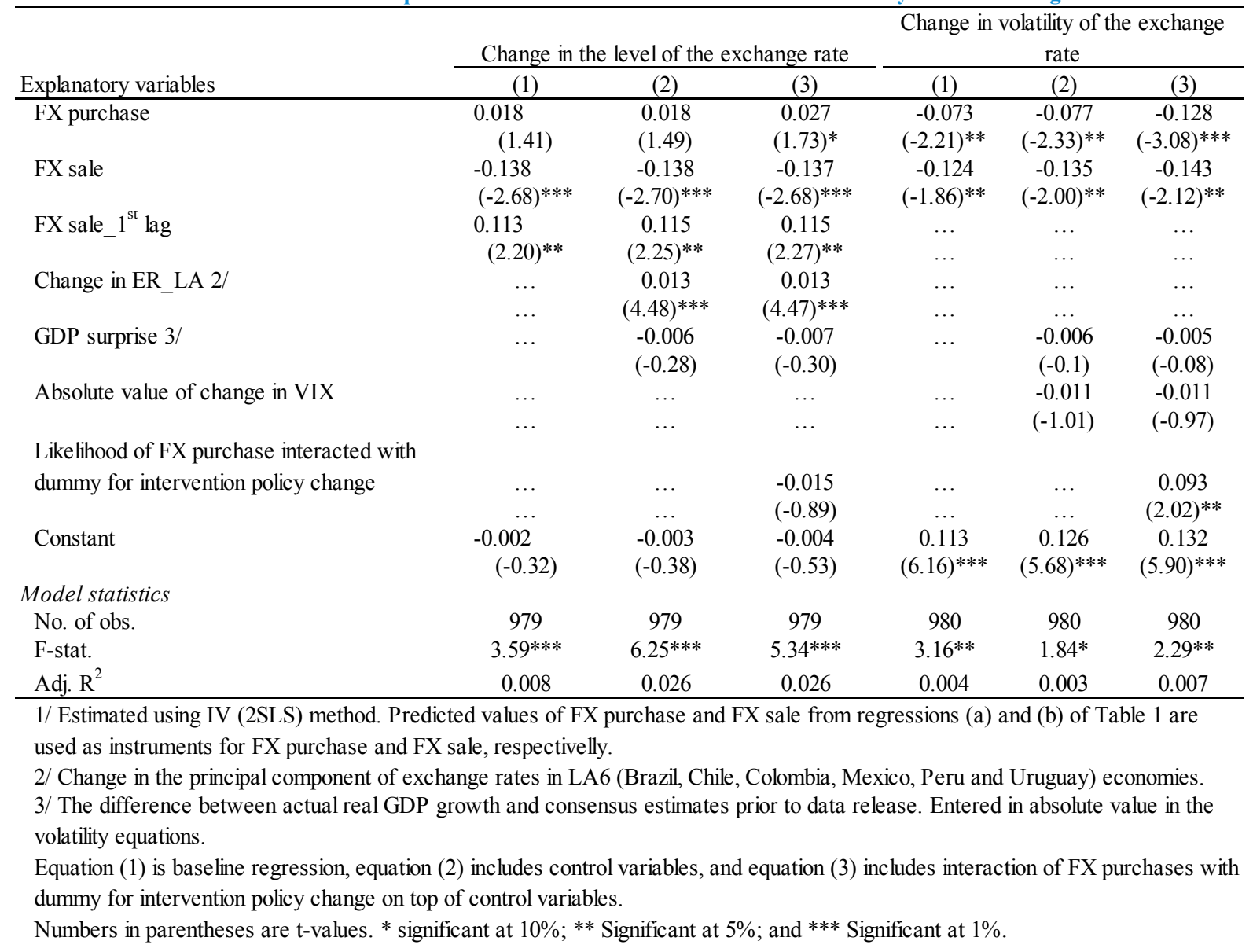




\section{CONCLUding REMARKS}

This study finds empirical evidence for asymmetry in BCRP's reactions to appreciation and depreciation pressures. While FX purchases are driven mainly by excessive appreciation of the exchange, FX sales respond to both excessive exchange rate volatility and excessive depreciation of the exchange rate. This implies that exchange rate volatility may be more of a concern for the BCRP during depreciation pressures than during appreciation pressures. In all regressions, excessive volatility is negatively associated with the likelihood of FX purchases by the BCRP and in some of the regressions it becomes statistically significant, albeit weakly, indicating that the BCRP might have intervened against very low volatility during appreciation episodes. This latter result is consistent with the BCRP's public statements in August 2012 that it was concerned by the low volatility and persistent appreciation of the nuevo sol and its decision to preannounce FX purchases of stable amounts even during days of depreciations.

While FX sales seem to be effective in preventing depreciation, there is no sufficient statistical evidence to support the success of FX purchases. The results show that FX sales by the BCRP are effective in reducing the level and volatility of the exchange rate. However, FX purchases do not have statistically significant impacts on the level of the exchange rate, while having unintended statistically significant negative impact on exchange rate volatility. The results also show that the BCRP's preannouncement of its interventions in August 2012 did not change the effectiveness of the intervention.

Since interventions can be costly, the BCRP needs to target its interventions where they are most effective. ${ }^{26}$ In this regard, the results of this study imply that:

- FX sales by the central bank can be warranted during periods of depreciation pressures if there are concerns of excessive volatility and depreciation. The statistical evidence in this study shows that FX sales are effective in reducing the excessive volatility and depreciation of the nuevo sol. But since these effects are found to be short-lived, interventions should not aim at preventing the depreciating trend of the exchange rate, which ought to be driven by fundamentals in any case.

- FX purchases by the central bank during periods of appreciation pressures are warranted mostly if volatility is a concern. ${ }^{27}$ If reducing volatility is not the objective, as the results of this study indicate, FX purchases could perpetuate the appreciation by reducing volatility and encouraging a one-sided bet on the domestic currency.

\footnotetext{
${ }^{26}$ The cost of sterilization in 2012 estimated at about $1 / 2$ percent of GDP.

${ }^{27}$ Building international reserves can also be a reason for intervention during episodes of appreciations although this is less likely to be the case in Peru recently.
} 


\section{AnNex I. Single EquATION REgRession of THE CENTRAL BANK's REACTION FunCtion}

Table. Peru: Multinomial logis tic regression of FX intervention $1 /$

\begin{tabular}{|c|c|c|c|c|}
\hline \multirow[b]{2}{*}{ Independent variable } & \multicolumn{2}{|c|}{$(1)$} & \multicolumn{2}{|c|}{ (2) } \\
\hline & FX sale & FX purchase & FX sale & FX purchase \\
\hline Intervention_ $1^{\text {st }}$ lag & $\begin{array}{l}-1.531 \\
(-4.49)^{* * *}\end{array}$ & $\begin{array}{c}2.636 \\
(11.04)^{* * *}\end{array}$ & $\begin{array}{c}-1.529 \\
(-4.49)^{* * *}\end{array}$ & $\begin{array}{c}2.439 \\
(10.15)^{* * *}\end{array}$ \\
\hline Intervention_ $2^{\text {nd }}$ lag & $\begin{array}{l}-0.798 \\
(-2.30)^{* *}\end{array}$ & $\begin{array}{c}0.853 \\
(3.57)^{* * *}\end{array}$ & $\begin{array}{c}-0.797 \\
(-2.30)^{* *}\end{array}$ & $\begin{array}{c}0.634 \\
(2.63)^{* * *}\end{array}$ \\
\hline Deviation from target (appreciation) & $\begin{array}{l}-71511 \\
(-0.02)\end{array}$ & $\begin{array}{c}45.131 \\
(5.12)^{* * *}\end{array}$ & $\begin{array}{l}-73835 \\
(-0.01)\end{array}$ & $\begin{array}{c}38.394 \\
(4.09)^{* * *}\end{array}$ \\
\hline Deviation from target (depreciation) & $\begin{array}{l}14.940 \\
(4.08)^{* * *}\end{array}$ & $\begin{array}{l}-9406 \\
(-0.00)\end{array}$ & $\begin{array}{c}14.850 \\
(4.06)^{* * *}\end{array}$ & $\begin{array}{l}-9170 \\
(-0.00)\end{array}$ \\
\hline Volatility & $\begin{array}{l}0.285 \\
(1.82)^{* *}\end{array}$ & $\begin{array}{l}-0.130 \\
(-0.68)\end{array}$ & $\begin{array}{c}0.284 \\
(1.81)^{* *}\end{array}$ & $\begin{array}{l}-0.300 \\
(-1.39)\end{array}$ \\
\hline $\begin{array}{l}\text { Deviation from target (appreciation) } \\
\text { for intervention policy change }\end{array}$ & $\begin{array}{l}\cdots \\
\cdots\end{array}$ & $\begin{array}{l}\cdots \\
\cdots\end{array}$ & $\begin{array}{l}56546 \\
(0.01)\end{array}$ & $\begin{array}{l}519.424 \\
(2.39)^{* *}\end{array}$ \\
\hline $\begin{array}{l}\text { Volatility*dummy for intervention po } \\
\text { change }\end{array}$ & $\begin{array}{l}\cdots \\
\cdots\end{array}$ & $\begin{array}{l}\cdots \\
\cdots\end{array}$ & $\begin{array}{l}-1.783 \\
(-0.42)\end{array}$ & $\begin{array}{l}-1.453 \\
(-1.39)\end{array}$ \\
\hline Constant & $\begin{array}{l}-2.703 \\
(-9.22)^{* * *}\end{array}$ & $\begin{array}{c}-2.668 \\
(-12.63)^{* * *}\end{array}$ & $\begin{array}{c}-2.693 \\
(-9.19)^{* * *}\end{array}$ & $\begin{array}{c}-2.516 \\
(-11.78)^{* * *}\end{array}$ \\
\hline Model statistics & & & & \\
\hline No. of observations & & & & 80 \\
\hline LR-chi' ${ }^{2}(10)$ & 877 & $2 * * *$ & 909 & $20 * * *$ \\
\hline Pseudo $\mathrm{R}^{2}$ & & & & 52 \\
\hline
\end{tabular}

$1 /$ The dependent variable is a dummy taking values of 1 for FX purchase, -1 for FX sale, and 0 otherwise. The base outcome is no-intervention.

Equations (1) and (2) are without and with, respectively, intervention policy change dummy interaction.

Numbers in parentheses are z-values. * significant at 10\%; ** Significant at 5\%; and *** Significant at 1\%. 


\section{Annex II. The Exchange Rate Target Estimated By Six Months Moving AVERAge EXChange RATe}

Table 1. Peru: Probit regression results for the probability of FX intervention $1 /$

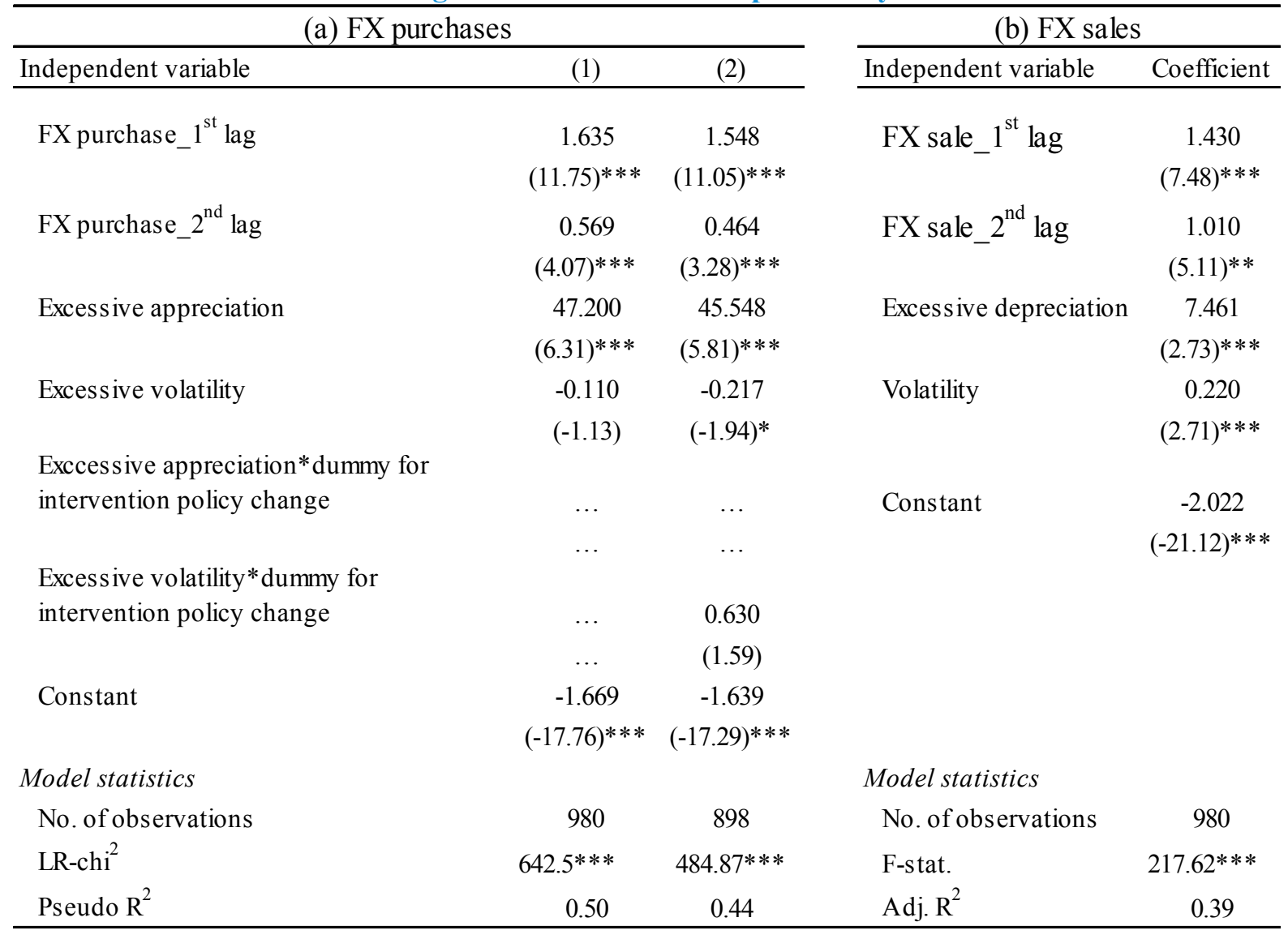

1/ Purchase and sale of FX are represented by dummy variables with values of 1 when there was purchase (sale) and 0 otherwise.

2/ Dropped from equation 2 as it predicts success perfectly.

Equations (1) and (2) are without and with intervention policy change dummy interaction, respectively.

Numbers in parentheses are z-values. * significant at 10\%; ** Significant at 5\%; and *** Significant at 1\%. 
Table 2. Peru: Estimated impacts of FX intervention on the level and volatility of the exchange rate $1 /$

\begin{tabular}{|c|c|c|c|c|c|c|}
\hline \multirow[b]{2}{*}{ Explanatory variables } & \multicolumn{3}{|c|}{ Change in the level of the exchange rate } & \multicolumn{3}{|c|}{ Change in volatility of the exchange rate } \\
\hline & (1) & (2) & (3) & (1) & (2) & (3) \\
\hline \multirow[t]{2}{*}{ FX purchase } & 0.017 & 0.017 & 0.025 & -0.090 & -0.094 & -0.127 \\
\hline & $(1.32)$ & $(1.39)$ & $(1.70)$ & $(-2.73)^{* * *}$ & $(-2.84)^{* * *}$ & $(-3.28)^{* * *}$ \\
\hline \multirow[t]{2}{*}{ FX sale } & -0.133 & -0.126 & -0.126 & -0.170 & -0.179 & -0.181 \\
\hline & $(-3.07)^{* * *}$ & $(-2.94)^{* * *}$ & $(-2.94) * * *$ & $(-2.40)^{* *}$ & $(-2.51)^{* *}$ & $(-2.53)^{* *}$ \\
\hline \multirow[t]{2}{*}{ FX sale_1 $1^{\text {st }}$ lag } & 0.110 & 0.105 & 0.105 & $\ldots$ & $\ldots$ & $\ldots$ \\
\hline & $(2.55)^{* * *}$ & $(2.44)^{* *}$ & $(2.45)^{* *}$ & $\ldots$ & $\ldots$ & $\cdots$ \\
\hline \multirow[t]{2}{*}{ Change in ER_LA 2/ } & $\ldots$ & 0.013 & 0.013 & $\ldots$ & $\ldots$ & $\ldots$ \\
\hline & $\ldots$ & $(4.36)^{* * *}$ & $(4.36)^{* * *}$ & $\ldots$ & $\ldots$ & $\ldots$ \\
\hline \multirow[t]{2}{*}{ GDP surprise 3/ } & $\cdots$ & -0.007 & -0.008 & $\ldots$ & -0.006 & -0.005 \\
\hline & & $(-0.33)$ & $(-0.35)$ & & $(-0.09)$ & $(-0.08)$ \\
\hline \multirow[t]{2}{*}{ Absolute value of change in VIX } & $\ldots$ & $\cdots$ & $\ldots$ & $\ldots$ & -0.012 & -0.011 \\
\hline & $\ldots$ & $\ldots$ & $\ldots$ & $\ldots$ & $(-1.05)$ & $(-0.98)$ \\
\hline \multirow[t]{2}{*}{$\begin{array}{l}\text { Likelihood of FX purchase interacted with } \\
\text { dummy for intervention policy change }\end{array}$} & $\ldots$ & $\ldots$ & -0.017 & $\ldots$ & $\ldots$ & 0.079 \\
\hline & $\ldots$ & $\ldots$ & $(-0.98)$ & $\ldots$ & $\ldots$ & $(1.67)^{*}$ \\
\hline \multirow[t]{2}{*}{ Constant } & -0.002 & -0.002 & -0.003 & 0.123 & 0.136 & 0.138 \\
\hline & $(-0.29)$ & $(-0.33)$ & $(-0.41)$ & $(6.64)^{* * *}$ & $(6.18)^{* * *}$ & $(6.23)^{* * *}$ \\
\hline \multicolumn{7}{|l|}{ Model statistics } \\
\hline No. of obs. & 979 & 979 & 979 & 980 & 980 & 980 \\
\hline F-stat. & $4.10^{* * *}$ & $6.36^{* * *}$ & $5.46^{* * *}$ & $5.08 * * *$ & $2.82 * *$ & $2.81 * *$ \\
\hline Adj. $R^{2}$ & 0.010 & 0.027 & 0.027 & 0.008 & 0.007 & 0.009 \\
\hline
\end{tabular}

1/ Estimated using IV (2SLS) method. Statistically significant variables in regressions (1) and (2) of Table IIa are used as instruments for likelihood of FX sales and purchases, respectively.

2/ Change in the principal component of exchange rates in LA6 (Brazil, Chile, Colombia, Mexico, Peru and Uruguay) economies.

3/ The difference between actual real GDP growth and conSensus estimates prior to data release. Entered in absolute value in the volatility equations.

Equation (1) is baseline regression, equation (2) includes control variables, and equation (3) includes interaction of FX purchases with dummy for intervention policy change on top of control variables.

Numbers in parentheses are t-values. * significant at $10 \%$;* Significant at $5 \%$; and *** Significant at $1 \%$. 


\section{Annex III. The Exchange Rate Target Estimated By One Year AVerage Rolling HP FilTERED EXCHANGE RATE}

Table 1. Peru: Probit re gression results for the probability of FX intervention $1 /$

\begin{tabular}{|c|c|c|c|c|}
\hline \multicolumn{3}{|c|}{ (a) FX purchases } & \multicolumn{2}{|c|}{ (b) FX sales } \\
\hline Independent variable & $(1)$ & (2) & Independent variable & Coefficient \\
\hline FX purchase_1 $1^{\text {st }}$ lag & $\begin{array}{c}1.620 \\
(11.65)^{* * *}\end{array}$ & $\begin{array}{c}1.519 \\
(10.80)^{* * *}\end{array}$ & FX sale_ $1^{\text {st }}$ lag & $\begin{array}{c}1.072 \\
(5.34)^{* * *}\end{array}$ \\
\hline FX purchase_ $2^{\text {nd }}$ lag & $\begin{array}{c}0.531 \\
(3.80)^{* * *}\end{array}$ & $\begin{array}{c}0.405 \\
(2.85)^{* * *}\end{array}$ & FX sale_ $2^{\text {nd }}$ lag & $\begin{array}{c}0.660 \\
(3.16)^{* *}\end{array}$ \\
\hline Excessive appreciation & $\begin{array}{c}31.935 \\
(6.73)^{* * *}\end{array}$ & $\begin{array}{c}29.668 \\
(5.88)^{* * *}\end{array}$ & Excessive depreciation & $\begin{array}{c}13.784 \\
(7.01)^{* * *}\end{array}$ \\
\hline Excessive volatility & $\begin{array}{l}-0.115 \\
(-1.16)\end{array}$ & $\begin{array}{c}-0.220 \\
(-1.94)^{*}\end{array}$ & Volatility & $\begin{array}{c}0.283 \\
(3.52)^{* * *}\end{array}$ \\
\hline $\begin{array}{l}\text { Exccessive appreciation*du } \\
\text { intervention policy change }\end{array}$ & $\begin{array}{l}\cdots \\
\cdots\end{array}$ & $\begin{array}{l}323.227 \\
(2.39)^{* *}\end{array}$ & Constant & $\begin{array}{c}-2.254 \\
(-19.14)^{* * *}\end{array}$ \\
\hline $\begin{array}{l}\text { Excessive volatility*dummy } \\
\text { intervention policy change }\end{array}$ & $\begin{array}{l}\ldots \\
\ldots\end{array}$ & $\begin{array}{l}-0.675 \\
(-1.14)\end{array}$ & & \\
\hline Constant & $\begin{array}{c}-1.773 \\
(-17.31)^{* * *}\end{array}$ & $\begin{array}{c}-1.720 \\
(-16.52)^{* * *}\end{array}$ & & \\
\hline $\begin{array}{l}\text { Model statistics } \\
\text { No. of observations }\end{array}$ & 980 & 980 & $\begin{array}{l}\text { Model statistics } \\
\text { No. of observations }\end{array}$ & 980 \\
\hline LR-chi $^{2}(4)$ & $648.38^{* * *}$ & $6678.62 * * *$ & F-stat. & $260.23^{* * *}$ \\
\hline Pseudo $\mathrm{R}^{2}$ & 0.51 & 0.53 & Adj. $R^{2}$ & 0.47 \\
\hline
\end{tabular}

1/ Purchase and sale of FX are represented by dummy variables with values of 1 when there was purchase (sale) and 0 otherwise.

Equations (1) and (2) are without and with intervention policy change dummy interaction, respectively.

Numbers in parentheses are z-values. * significant at $10 \%$;* Significant at $5 \%$; and $* * *$ Significant at $1 \%$. 
Table 2. Peru: Estimate d impacts of FX intervention on the level and volatility of the exchange rate $1 /$

\begin{tabular}{|c|c|c|c|c|c|c|}
\hline \multirow[b]{2}{*}{ Explanatory variables } & \multicolumn{3}{|c|}{ Change in the level of the exchange rate } & \multicolumn{3}{|c|}{ Change in volatility of the exchange rate } \\
\hline & $(1)$ & (2) & (3) & $(1)$ & (2) & (3) \\
\hline FX purchase & $\begin{array}{l}0.018 \\
\quad(1.42)\end{array}$ & $\begin{array}{l}0.019 \\
(1.49)\end{array}$ & $\begin{array}{c}0.027 \\
(1.72)^{*}\end{array}$ & $\begin{array}{c}-0.072 \\
(-2.20)^{* *}\end{array}$ & $\begin{array}{c}-0.077 \\
(-2.32)^{* *}\end{array}$ & $\begin{array}{c}-0.128 \\
(-3.07)^{* * *}\end{array}$ \\
\hline FX sale & $\begin{array}{l}-0.138 \\
(-2.68)^{* * *}\end{array}$ & $\begin{array}{c}-0.137 \\
(-2.69)^{* * *}\end{array}$ & $\begin{array}{c}-0.136 \\
(-2.67)^{* * *}\end{array}$ & $\begin{array}{c}-0.124 \\
(-1.86)^{* *}\end{array}$ & $\begin{array}{c}-0.135 \\
(-2.00)^{* *}\end{array}$ & $\begin{array}{c}-0.143 \\
(-2.12)^{* *}\end{array}$ \\
\hline FX sale_1 $1^{\text {st }}$ lag & $\begin{array}{l}0.113 \\
(2.20)^{* *}\end{array}$ & $\begin{array}{c}0.114 \\
(2.25)^{* *}\end{array}$ & $\begin{array}{c}0.115 \\
(2.26)^{* *}\end{array}$ & $\begin{array}{l}\cdots \\
\ldots\end{array}$ & $\begin{array}{l}\cdots \\
\ldots\end{array}$ & $\begin{array}{l}\cdots \\
\ldots\end{array}$ \\
\hline Change in ER_LA 2/ & $\begin{array}{l}\cdots \\
\ldots\end{array}$ & $\begin{array}{c}0.013 \\
(4.45)^{* * *}\end{array}$ & $\begin{array}{c}0.013 \\
(4.44)^{* * *}\end{array}$ & $\begin{array}{l}\cdots \\
\ldots\end{array}$ & $\begin{array}{l}\cdots \\
\ldots\end{array}$ & $\begin{array}{l}\cdots \\
\ldots\end{array}$ \\
\hline GDP surprise 3/ & $\ldots$ & $\begin{array}{l}-0.007 \\
(-0.30)\end{array}$ & $\begin{array}{l}-0.007 \\
(-0.32)\end{array}$ & $\ldots$ & $\begin{array}{l}-0.006 \\
(-0.10)\end{array}$ & $\begin{array}{l}-0.005 \\
(-0.08)\end{array}$ \\
\hline Absolute value of change in VIX & $\begin{array}{l}\cdots \\
\ldots\end{array}$ & $\begin{array}{l}\ldots \\
\ldots\end{array}$ & $\begin{array}{l}\cdots \\
\ldots\end{array}$ & $\begin{array}{l}\cdots \\
\ldots\end{array}$ & $\begin{array}{l}-0.011 \\
(-1.03)\end{array}$ & $\begin{array}{l}-0.016 \\
(-1.49)\end{array}$ \\
\hline $\begin{array}{l}\text { Likelihood of FX purchase interacted with } \\
\text { dummy for intervention policy change }\end{array}$ & $\begin{array}{l}\ldots \\
\ldots\end{array}$ & $\begin{array}{l}\ldots \\
\ldots\end{array}$ & $\begin{array}{l}-0.015 \\
(-0.88)\end{array}$ & $\begin{array}{l}\cdots \\
\ldots\end{array}$ & $\begin{array}{l}\cdots \\
\ldots\end{array}$ & $\begin{array}{c}0.093 \\
(2.02)^{* *}\end{array}$ \\
\hline Constant & $\begin{array}{l}-0.002 \\
(-0.33)\end{array}$ & $\begin{array}{l}-0.003 \\
(-0.38)\end{array}$ & $\begin{array}{l}-0.004 \\
(-0.53)\end{array}$ & $\begin{array}{c}0.113 \\
(6.15)^{* * *}\end{array}$ & $\begin{array}{c}0.126 \\
(5.68)^{* * *}\end{array}$ & $\begin{array}{c}0.132 \\
(5.90) * * *\end{array}$ \\
\hline Model statistics & & & & & & \\
\hline No. of obs. & 979 & 979 & 979 & 980 & 980 & 980 \\
\hline F-stat. & $3.59 * * *$ & $6.20 * * *$ & $5.30 * * *$ & $3.14 * *$ & $1.83^{*}$ & $2.28^{* *}$ \\
\hline Adj. $R^{2}$ & 0.008 & 0.026 & 0.026 & 0.004 & 0.003 & 0.007 \\
\hline
\end{tabular}

1/ Estimated using IV (2SLS) method. Statistically significant variables in regressions (1) and (2) of Table IIIa are used as instruments for likelihood of FX sales and purchases, respectively.

2/ Change in the principal component of exchange rates in LA6 (Brazil, Chile, Colombia, Mexico, Peru and Uruguay) economies.

3/ The difference between actual real GDP growth and consensus estimates prior to data release. Entered in absolute value in the volatility equations.

Equation (1) is baseline regression, equation (2) includes control variables, and equation (3) includes interaction of FX purchases with dummy for intervention policy change on top of control variables.

Numbers in parentheses are t-values. * significant at $10 \%$;* Significant at $5 \%$; and $* * *$ Significant at $1 \%$. 


\section{Annex IV. Tolerable Range Defined As 1-Year Historical AVerage Exchange RATE \pm 1.5 TIMES STANDARD DEVIATION}

Table 1. Peru: Probit regression results for the probability of FX intervention $1 /$

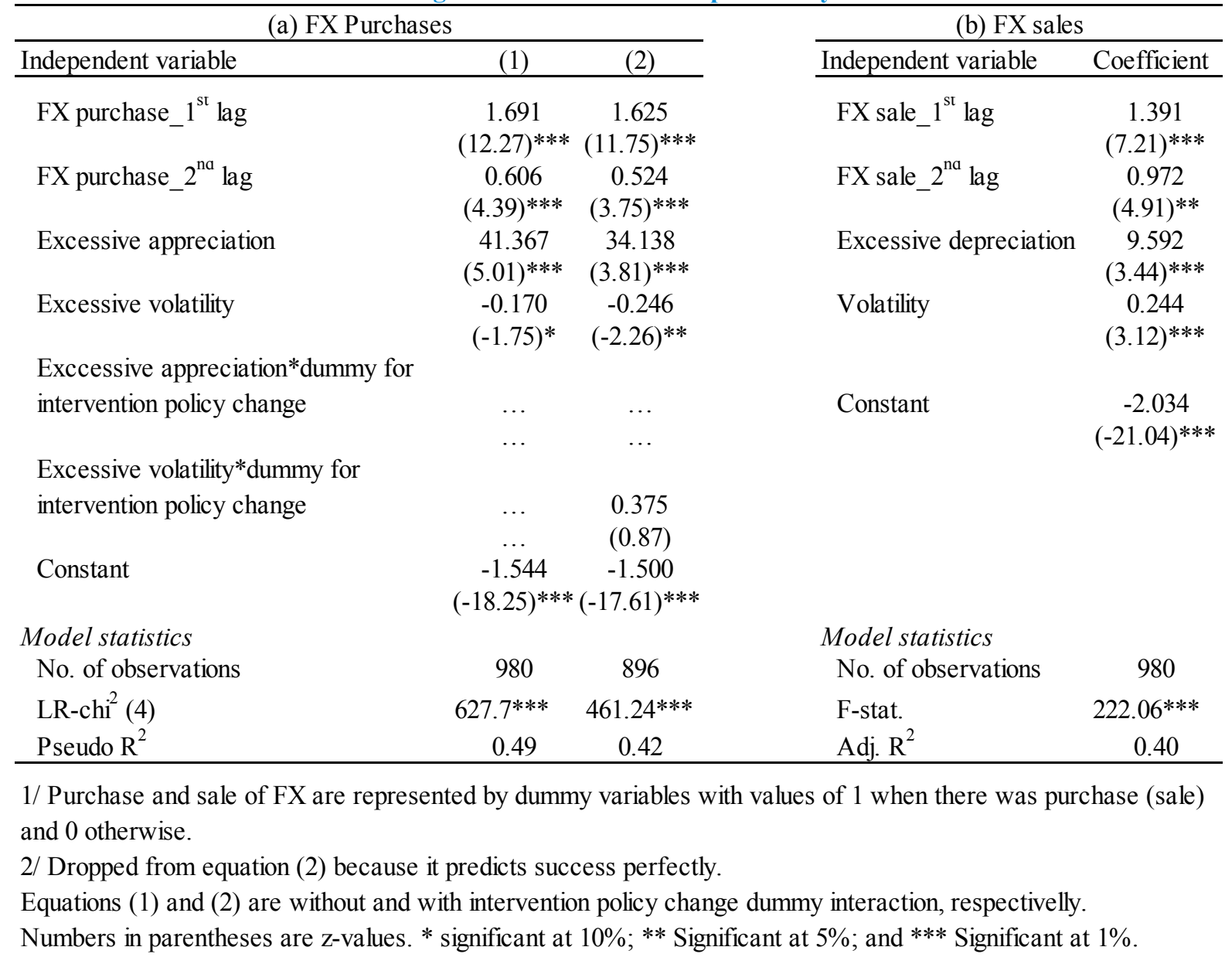


Table 2. Peru: Estimate d impacts of FX intervention on the level and volatility of the exchange rate $1 /$

\begin{tabular}{|c|c|c|c|c|c|c|}
\hline \multirow[b]{2}{*}{ Explanatory variables } & \multicolumn{3}{|c|}{ Change in the level of the exchange rate } & \multicolumn{3}{|c|}{ Change in volatility of the exchange rate } \\
\hline & (1) & (2) & (3) & (1) & (2) & (3) \\
\hline FX purchase & $\begin{array}{l}0.015 \\
\quad(1.20)\end{array}$ & $\begin{array}{l}0.016 \\
(1.25)\end{array}$ & $\begin{array}{l}0.024 \\
(1.57)\end{array}$ & $\begin{array}{c}-0.082 \\
(-2.48)^{* *}\end{array}$ & $\begin{array}{c}-0.086 \\
(-2.58)^{* *}\end{array}$ & $\begin{array}{c}-0.123 \\
(-3.08)^{* * *}\end{array}$ \\
\hline FX sale & $\begin{array}{l}-0.136 \\
(-3.08)^{* * *}\end{array}$ & $\begin{array}{c}-0.130 \\
(-2.98)^{* * *}\end{array}$ & $\begin{array}{c}-0.130 \\
(-2.98)^{* * *}\end{array}$ & $\begin{array}{c}-0.180 \\
(-2.58)^{* * *}\end{array}$ & $\begin{array}{c}-0.189 \\
(-2.68)^{* * *}\end{array}$ & $\begin{array}{c}-0.192 \\
(-2.72)^{* * *}\end{array}$ \\
\hline FX sale_1 $1^{\text {st }}$ lag & $\begin{array}{l}0.107 \\
(2.42)^{* *}\end{array}$ & $\begin{array}{c}0.103 \\
(2.35)^{* *}\end{array}$ & $\begin{array}{c}0.103 \\
(2.36)^{* *}\end{array}$ & $\begin{array}{l}\cdots \\
\cdots\end{array}$ & $\begin{array}{l}\cdots \\
\cdots\end{array}$ & $\begin{array}{l}\cdots \\
\cdots\end{array}$ \\
\hline Change in ER_LA 2/ & $\begin{array}{l}\cdots \\
\ldots\end{array}$ & $\begin{array}{c}0.013 \\
(4.37)^{* * *}\end{array}$ & $\begin{array}{c}0.013 \\
(4.36)^{* * *}\end{array}$ & $\begin{array}{l}\cdots \\
\ldots\end{array}$ & $\begin{array}{l}\cdots \\
\ldots\end{array}$ & $\begin{array}{l}\cdots \\
\ldots\end{array}$ \\
\hline GDP surprise 3/ & $\cdots$ & $\begin{array}{l}-0.007 \\
(-0.33)\end{array}$ & $\begin{array}{l}-0.008 \\
(-0.34)\end{array}$ & $\cdots$ & $\begin{array}{l}-0.007 \\
(-0.12)\end{array}$ & $\begin{array}{l}-0.006 \\
(-0.10)\end{array}$ \\
\hline Absolute value of change in VIX & $\begin{array}{l}\cdots \\
\ldots\end{array}$ & $\begin{array}{l}\cdots \\
\ldots\end{array}$ & $\begin{array}{l}\cdots \\
\ldots\end{array}$ & $\begin{array}{l}\cdots \\
\ldots\end{array}$ & $\begin{array}{l}-0.011 \\
(-1.03)\end{array}$ & $\begin{array}{l}-0.011 \\
(-0.96)\end{array}$ \\
\hline $\begin{array}{l}\text { Likelihood of FX purchase interacted with } \\
\text { dummy for intervention policy change }\end{array}$ & $\begin{array}{l}\cdots \\
\ldots\end{array}$ & $\begin{array}{l}\cdots \\
\ldots\end{array}$ & $\begin{array}{l}-0.017 \\
(-0.96)\end{array}$ & $\begin{array}{l}\cdots \\
\ldots\end{array}$ & $\begin{array}{l}\cdots \\
\ldots\end{array}$ & $\begin{array}{c}0.078 \\
(1.68)^{*}\end{array}$ \\
\hline Constant & $\begin{array}{l}-0.001 \\
\quad(-0.16)\end{array}$ & $\begin{array}{l}-0.001 \\
(-0.18)\end{array}$ & $\begin{array}{l}-0.002 \\
(-0.29)\end{array}$ & $\begin{array}{c}0.121 \\
(6.53)^{* * *}\end{array}$ & $\begin{array}{c}0.134 \\
(6.09)^{* * *}\end{array}$ & $\begin{array}{c}0.137 \\
(6.17)^{* * *}\end{array}$ \\
\hline Model statistics & & & & & & \\
\hline No. of obs. & 979 & 979 & 979 & 980 & 980 & 960 \\
\hline F-stat. & $4.05 * * *$ & $6.35^{* * *}$ & $5.45^{* * *}$ & $4.92 * * *$ & $2.72 * *$ & $2.72 * *$ \\
\hline Adj. $R^{2}$ & 0.010 & 0.027 & 0.027 & 0.008 & 0.007 & 0.009 \\
\hline
\end{tabular}

1/ Estimated using IV (2SLS) method. Statistically significant variables in regressions (1) and (2) of Table IVa are used as instruments for likelihood of FX sales and purchases, respectively.

2/ Change in the principal component of exchange rates in LA6 (Brazil, Chile, Colombia, Mexico, Peru and Uruguay) economies.

3/ The difference between actual real GDP growth and consensus estimates prior to data release. Entered in absolute value in the volatility equations.

Equation (1) is baseline regression, equation (2) includes control variables, and equation (3) includes interaction of FX purchases with dummy for intervention policy change on top of control variables.

Numbers in parentheses are t-values. * significant at $10 \%$;* Significant at $5 \%$; and $* * *$ Significant at $1 \%$. 


\section{REFERENCES}

Adler, Gustavo, and Camilo E. Tovar, 2011, "Foreign Exchange Intervention: A Shield Against Appreciation Winds?”, IMF Working Paper No. 11/165 (Washington: International Monetary Fund.)

Baillie, Richard T., and William P. Osterberg, 1997, "Why Do Central Banks Intervene?" Journal of International Money and Finance, Vol.16, pp. 909-19.

Banco Central de Reserva del Peru (BCRP), 2012, Inflation Report: Recent Trends and Macroeconomic Forecasts 2012-2014, December 2012.

Broto, Carmen, 2013, “The Effectiveness of Forex Interventions in Four Latin American Countries," Emerging Markets Review, Vol. 17, pp. 224-240.

Cardarelli, R., Selim Elekdag, M. Ayhan Kose, 2010, “Capital inflows: Macroeconomic Implications and Policy Responses,” Economic Systems, Vol. 34, No. 4, pp. 333-356.

Disyatat, Piti, and Gabriele Galati, 2007, "The Effectiveness of Foreign Exchange Intervention in Emerging Market Countries: Evidence from the Czech Koruna," Journal of International Money and Finance, Vol. 26, No. 3, pp. 383-402.

Dominguez, Kathryn M. E., 2003, “The Market Microstructure of Central Bank Intervention,” Journal of International Economics, Vol. 59, No. 1, pp. 25-45.

Dominguez, Kathryn M. E., 2006, "When Do Central Bank Interventions Influence Intra-Daily and Longer-Term Exchange Rate Movements?" Journal of International Money and Finance, Vol. 25, No. 7, pp. 1051-1071.

Dominguez, Kathryn M., and Jeffrey A. Frankel, 1993, "Does Foreign-Exchange Intervention Matter? The Portfolio Effect," American Economic Review, Vol. 83, pp. 1356-69.

Fatum, Rasmus, and Michael M. Hutchison, 2003, "Is Sterilized Foreign Exchange Intervention Effective After All? An Event Study Approach," Economic Journal: The Journal of the Royal Economic Society, Vol. 113, No. 487, pp. 390-411.

Furceri, Davide, Stephanie Guicahrd, and Elena Rusticelli, 2012, "The Effect of Episodes of Large Capital Inflows on Domestic Credit," North American Journal of Economics and Finance, Vol. 23, No. 3, pp. 325-344.

Forbes, Kristin J., and Francis E. Warnock, 2012, "Capital flow waves: Surges, Stops, Flight, and Retrenchment," Journal of International Economics, Vol. 88, No. 2, pp. 235-251.

Galati, Gabriele, William Melick, and Marian Micu, 2005, "Foreign Exchange Market Intervention and Expectations: the yen/dollar Exchange Rate," Journal of International Money and Finance, Vol. 24, No. 6, pp. 982-1011.

Gonzalez, Maria, 2009, "Disentangling the Motives for Foreign Exchange Intervention in Peru," IMF Country Report No. 09/41 (Washington). 
Guimaraes, Roberto F., and Cem Karacadag, 2004, "The Empirics of Foreign Exchange Intervention in Emerging Market Countries: the Cases of Mexico and Turkey," IMF Working Paper 04/123 (Washington: International Monetary Fund).

Humala, Alberto and Gabriel, Rodriguez, 2009, "Foreign Exchange Intervention and Exchange Rate Volatility in Peru," Banco Central de Reserve del Peru Working Paper Series No.2009-008 (Peru).

Kearns, Jonathan, and Roberto Rigobon, 2005, "Identifying the Efficacy of Central Bank Interventions: Evidence from Australia and Japan," Journal of International Economics, Vol. 66, No. 1, pp. 31-48.

Lahura, Erick, and Marco Vega, 2013, “Asymmetric Effects of FOREX Intervention Using Intraday Data: Evidence from Peru,” BIS Working Papers No. 430 (Basel: Bank for International Settlements).

Neely, Christopher J., 2001, "The Practice of Central Bank Intervention: Looking Under the Hood." Review/Federal Reserve Bank of St. Louis, Vol. 83, No. 3, pp. 1-10.

Pontines, Victor, and Ramkishen S. Rajan. 2011, "Foreign Exchange Market Intervention and Reserve Accumulation in Emerging Asia: Is There Evidence of Fear of Appreciation?" Economics Letters, Vol. 111, No. 3, pp. 252-255.

Ramachandran, M., and Naveen Srinivasan, 2007, "Asymmetric Exchange Rate Intervention and International Reserve Accumulation in India," Economics Letters, Vol. 94, No. 2, pp. 259-265.

Reinhart, Carmen M., and Vincent R. Reinhart, 2008, "Capital Flow Bonanzas: An Encompassing View of the Past and Present."

Rossini, Renzo, Zenon Quispe and Donita Rodriguez, 2011, "Capital flows, Monetary Policy and Forex Intervention in Peru,” BIS Working Papers No. 57 BIS Working Papers No. 430 (Basel: Bank for International Settlements).

Rossini, Renzo, Zenon Quispe and Enrique Serrano, 2013, "Foreign Exchange Intervention in Peru,” BIS Working Papers No. 73 BIS Working Papers No. 430 (Basel: Bank for International Settlements).

Sarno, Lucio, and Mark P. Taylor, 2001, "Official Intervention in the Foreign Exchange Market: Is It Effective And, If So, How Does It Work?” Journal of Economic Literature, Vol. 39, No. 3, pp. 839-68. 